\title{
Bariery dla innowacji i transferu techniki w Polsce oraz sposoby ich pokonywania
}

\begin{abstract}
Filip Tużnik*
Działalność w zakresie innowacji jest w ostatnim czasie głównym wyznacznikiem pozycji rynkowej przedsiębiorstw. Jednym z podstawowych wyzwań, przed którymi stoja menedżerowie, jest umiejętność radzenia sobie z barierami napotykanymi przy ich wdrażaniu. Skuteczne ich przezwyciężenie może wplynać na sukces firmy, a w skali makro na rozwój catej gospodarki. W niniejszym artykule zaprezentowano klasyfikację najczęściej pojawiających się barier $w$ działalności innowacyjnej przedsiębiorstw oraz w procesie transferu techniki. Przedstawiono $w$ nim podstawowe przeszkody o charakterze finansowym, problemy wynikajace ze wspótpracy pomiędzy sektorem nauki i biznesu, a także prawne aspekty negatywnie wplywajace na pracę innowatorów. Artykut zawiera również przeglad propozycji dotyczacych przeciwdziatania barierom rekomendowanych przez krajowych ekspertów i przedsiębiorców.
\end{abstract}

Słowa kluczowe: innowacje, transfer techniki, bariery innowacji.

Nadesłany: 07.02.2014 | Zaakceptowany do druku: 14.05.2014

\section{Barriers for innovation and technology transfer in Poland and methods of overcoming them}

One of the main determinants of companies' market rating is their innovative activity. Though, many managers must cope with barriers they encounter while implementing new technologies. The effectiveness in overcoming barriers could have an influence on company's success and development of the national economy. This article focuses on classification of the main barriers that appear during innovative activity and the technology transfer process. There are three groups of barriers taken into consideration: these of financial origin, these arising between business and science, and those of legal origin. One can also find suggestions how to overcome barriers, given by domestic experts and entrepreneurs.

Keywords: innovation, technology transfer, barriers to innovation.

Submitted: 07.02.20014 | Accepted: 14.05.2014

JEL: O32.

\footnotetext{
Mgr inż. Filip Tużnik - Uniwersytet Warszawski, Wydział Zarządzania.

Adres do korespondencji: Uniwersytet Warszawski, Wydział Zarządzania, ul. Szturmowa 1/3, 2-678 Warszawa; e-mail: ftuznik@wz.uw.edu.pl; filiptuznik@yahoo.com.
} 


\section{Wstęp}

W dzisiejszym świecie innowacyjność stanowi czynnik weryfikujący pozycję przedsiębiorstw na rynku, a menedżerowie są w większości świadomi, że inwestowanie w innowacje stanowi szansę szybkiego rozwoju oraz zwiększenia konkurencyjności firmy w otoczeniu. Intensywny rozwój działalności innowacyjnej jest widoczny również w Polsce, gdzie w ciagu ostatnich dwóch dekad pojawiły się sprzyjające warunki do wprowadzania innowacji na rynek oraz intensyfikacji procesu transferu techniki.

Niniejszy artykuł w całości opiera się na źródłach wtórnych, a jego głównym celem jest chęć odnalezienia odpowiedzi na pytanie, $\mathrm{z}$ jakimi barierami spotykają się innowatorzy w Polsce i jak im skutecznie przeciwdziałać. Tezą zaś jest stwierdzenie, że rzetelne określenie barier w działalności innowacyjnej umożliwia podjęcie działań w celu skutecznego ich przezwyciężenia.

W artykule termin innowacja odnosi się do innowacji technologicznych, które A. Pomykalski definiuje jako ,nowe produkty i procesy oraz znaczące zmiany technologiczne w produktach i procesach" (Pomykalski, 2001, s. 26). Bariery są obecne w trakcie procesu innowacyjnego, który W. Janasz nazywa ciąiem zdarzeń zamykającym się w znaczeniu czynnościowym „W przedziale od pierwszej koncepcji do pierwszej realizacji” (Janasz, 1999, s. 71), a także w trakcie transferu techniki. Proces ten, jak pisze A. Jasiński, może mieć charakter pionowy, odbywać się pomiędzy jednostką naukowo-badawczą a przedsiębiorstwem i skutkować pojawieniem się innowacji na rynku lub poziomu, którego celem jest dyfuzja innowacji, rozumiana jako rozprzestrzenianie się innowacji pośród przedstawicieli danej branży (Jasiński, 2006, s. 23-26). Warto też wspomnieć za E. Rogersem, że obecnie już sama informacja o nowej technologii wykorzystana w celach użytkowych często stanowi transfer techniki (Rogers 2003, s. 150).

\section{Działalność innowacyjna w Polsce}

Coraz większa liczba rodzimych przedsiębiorstw angażuje się w działalność innowacyjną. Niestety, jak wskazuja wyniki badań przeprowadzone przez Komisję Europejską, Polska razem z Lotwą, Rumu- nią oraz Bułgarią wciąż znajdują się wśród najmniej innowacyjnych państw Unii Europejskiej, ze średnią innowacyjnością prawie trzykrotnie mniejszą od krajów-liderów innowacji, jak Finlandia, Dania, Niemcy czy Szwecja (Innovation Union Scoreboard, 2013, s. 10).

Można jednak znaleźć wiele polskich firm, które z powodzeniem realizują strategie innowacyjne i rozwijają się poprzez ciagłe ich wprowadzanie. Według GUS za działalność innowacyjną uważa się działania naukowe, organizacyjne, techniczne, finansowe i komercyjne, prowadzące lub mające prowadzić do wdrażania innowacji (GUS, 2013, s. 1). Dane GUS dotyczące tak rozumianej innowacyjności polskich przedsiębiorstw w latach 2009-2011 oraz 2010-2012 zostały przedstawione w tabeli 1 .

Wyniki badań wskazują na względne utrzymanie się niskiego poziomu innowacyjności polskich firm w latach 2010-2012 $\mathrm{W}$ porównaniu $\mathrm{z}$ okresem poprzednim. Relatywnie największy wzrost udziału innowacji odnotowano dla przedsiębiorstw usługowych wdrażających wyroby, gdzie ich poziom zwiększył się z 2,5 do 3,3\%. Największy spadek innowacyjności jest natomiast widoczny w przypadku innowacyjnych metod wspierających procesy, dla których udział firm przemysłowych zmniejszył się z 5,8 do $5,4 \%$, a firm usługowych $\mathrm{z} 7,0$ do $6,6 \%$.

W opracowaniu GUS można również znaleźć informacje na temat celów, jakie stawiają sobie polscy innowacyjni przedsiębiorcy. Najważniejszym $\mathrm{z}$ nich jest wzrost przychodów ze sprzedaży, na który wskazuje aż 56,4\% innowacyjnych firm z sektora przemysłowego i $59,4 \%$ z sektora usługowego. W drugiej kolejności respondenci chcą zmniejszenia kosztów działalności, a cel ten wskazuje $47,8 \%$ firm przemysłowych i 46,4\% firm usługowych (GUS, 2013, s. 5).

Takie wyniki pokazują kierunek działań polskich innowatorów, którzy będą dążyli do zintensyfikowania sprzedaży, a także usprawnienia procesów logistycznych i dystrybucyjnych w swoich firmach. Pomocna w realizacji opisanych powyżej celów może okazać się umiejętność przezwyciężania barier innowacji, z którymi wielu $\mathrm{z}$ nich od dawna ma do czynienia, a które niejednokrotnie są przyczyną niskich przychodów ze sprzedaży i wysokich kosztów prowadzenia działalności innowacyjnej. 
Tabela 1. Procentowy udziat innowacji wśród polskich przedsiębiorstw w latach 2009-2011 oraz 2010-2012

\begin{tabular}{|c|c|c|c|c|}
\hline $\begin{array}{l}\text { Charakter } \\
\text { innowacji }\end{array}$ & Rodzaj innowacji & $\begin{array}{c}\text { Typ } \\
\text { przedsiębiorstwa }\end{array}$ & $\begin{array}{c}\text { Udzial firm } \\
\text { innowacyjnych } \\
\text { w latach } \\
\text { 2009-2011 (\%) }\end{array}$ & $\begin{array}{c}\text { Udział firm } \\
\text { innowacyjnych } \\
\text { w latach } \\
\text { 2010-2012 (\%) }\end{array}$ \\
\hline \multirow{4}{*}{$\begin{array}{l}\text { Innowacje } \\
\text { produktowe }\end{array}$} & \multirow{2}{*}{ wyroby } & przemysłowe & 10,4 & 10,5 \\
\hline & & usługowe & 2,5 & 3,3 \\
\hline & \multirow{2}{*}{ usługi } & przemysłowe & 2,6 & 2,6 \\
\hline & & usługowe & 5,0 & 4,8 \\
\hline \multirow{6}{*}{$\begin{array}{l}\text { Innowacje } \\
\text { procesowe }\end{array}$} & \multirow{2}{*}{$\begin{array}{l}\text { metody wytwarzania } \\
\text { wyrobów }\end{array}$} & przemysłowe & 9,7 & 9,7 \\
\hline & & usługowe & 2,8 & 3,0 \\
\hline & \multirow{2}{*}{$\begin{array}{l}\text { metody z zakresu } \\
\text { logistyki i dystrybucji }\end{array}$} & przemysłowe & 3,0 & 3,0 \\
\hline & & usługowe & 3,6 & 3,5 \\
\hline & \multirow{2}{*}{$\begin{array}{l}\text { metody wspierające } \\
\text { procesy }\end{array}$} & przemysłowe & 5,8 & 5,4 \\
\hline & & usługowe & 7,0 & 6,6 \\
\hline
\end{tabular}

Źródło: opracowanie własne na podstawie GUS, 2013.

\section{Rodzaje barier w działalności innowacyjnej}

Bariery w działalności innowacyjnej mogą mieć różny charakter. Pojawiają się we wszystkich etapach procesu innowacyjnego: w trakcie prac nad nowym pomysłem, w czasie rozwoju i testowania nowości, a także później w procesie komercjalizacji produktu. Są obecne podczas tzw. pionowego transferu techniki, gdy innowacja przebywa drogę ze świata nauki do świata biznesu, w procesie poziomego transferu techniki, gdy rozpowszechnia się ona wśród przedsiębiorców, jak również po jej skutecznym wdrożeniu, przy okazji akcji promujących innowacyjne rozwiązanie na rynku.

Dodatkowo, działalności innowacyjnej towarzyszy ryzyko, przejawiające się w możliwości wystąpienia strat, niebezpieczeństw lub zagrożeń dla przedsiębiorcy - innowatora. Według Janasza może ono mieć charakter: (1) ryzyka właściwego, wynikającego z prawa wielkich liczb; (2) ryzyka subiektywnego, opisującego subiektywną ocenę prawdopodobieństwa określonych zdarzeń przez człowieka oraz (3) ryzyka obiektywnego, odnoszącego się do zjawisk absolutnie niepewnych czy wręcz nieprzewidywalnych (Janasz, 2003, s. 236-245).

$\mathrm{Z}$ ryzykiem w działalności innowacyjnej wiąże się powstawanie barier. Jak wynika z badań Puchały-Krzywiny, która prze- prowadziła ankietę wśród 500 najbardziej innowacyjnych przedsiębiorstw w Polsce, rodzimi przedsiębiorcy innowacyjni zdają sobie sprawę z ich występowania. Poproszeni o wskazanie najważniejszych czynników utrudniających działalność innowacyjną, zwracają uwage na następujące bariery (Puchała-Krzywina, 2011, s. 164-168):

1) brak środków własnych;

2) brak zewnętrznych środków finansowych;

3) zbyt wysokie koszty prowadzenia działalności innowacyjnej;

4) brak wystarczającej informacji o rynku, na który ma być wprowadzona innowacja;

5) brak pełnej wiedzy o charakterystyce technologii innowacyjnej;

6) nieprzewidywalny poziom popytu na innowacyjne produkty;

7) problemy w trakcie poszukiwania partnerów do wspólpracy;

8) brak wykwalifikowanego personelu;

9) brak odpowiedniego nadzoru innowacji po jej wdrożeniu, co prowadzi do problemów efektywnym wykorzystaniem jej potencjału na rynku;

10) opanowanie rynku przez podmioty duże, dominujące, dysponujące większym kapitałem i siła przebicia na rynku;

11) brak wystarczającego popytu na innowacje. 
Wśród wymienionych barier można wyodrębnić kilka ich grup o podobnej genezie powstawania. Pierwsze trzy z nich maja wyraźny charakter finansowy i są związane z brakiem środków na realizację celów innowacyjnych. Trzy kolejne wynikają z niewystarczającej wiedzy innowatorów o rynku oraz potencjale innowacji. Następne trzy bariery tworzą grupę przeszkód o podłożu organizacyjnym, a ostatnie dwie wskazuja na istotne zjawisko gospodarcze, jakim jest proces przejmowania rynków przez większe podmioty i związany z nim spadek popytu na krajowe innowacje.

Cztery główne grupy barier w działalności innowacyjnej wskazuje też GUS, na podstawie badania przeprowadzonego wśród polskich przedsiębiorstw. Znajdują się wśród nich czynniki o charakterze finansowym, czynniki związane $\mathrm{z}$ wiedzą, czynniki rynkowe oraz pozostałe, niesklasyfikowane $\mathrm{w}$ żadnej $\mathrm{z}$ grup. Procentowy udział firm różnej wielkości, które zaobserwowały w swojej działalności występowanie poszczególnych barier został przedstawiony $\mathrm{w}$ tabeli 2 (GUS, 2011, s. 81-82).

$\mathrm{Na}$ podstawie tabeli 2 można wyciągnąć ogólny wniosek, że im przedsiębiorstwa są mniejsze, tym większy odsetek ich właścicieli wskazuje na istnienie barier, niezależnie od ich rodzaju. I tak, najczęściej wskazują na nie przedstawiciele firm zatrudniających poniżej 49 osób. Najrzadziej widzą bariery przedstawiciele podmiotów o liczbie pracowników powyżej 500 lub, dla kilku barier, firmy o liczbie zatrudnionych pomiędzy 250-499.

Wśród barier, niezależnie od wielkości ankietowanych firm, ich przedstawiciele najczęściej wskazują na te o charakterze finansowym, a więc brak środków finansowych w przedsiębiorstwie, brak środków finansowych ze źródeł zewnętrznych oraz zbyt wysokie koszty innowacji. Ostatnia $z$ tych barier została wskazana przez największą liczbę przedsiębiorstw, niezależnie od ich wielkości, a wśród firm zatrudniających poniżej 49 pracowników osiągnęła najwyższą ze wszystkich pozycji wartość,

Tabela 2. Procentowy udział polskich przedsiębiorstw przemysłowych, które odczuwały wyszczególnione bariery w działalności innowacyjnej w latach 2008-2010

\begin{tabular}{|c|c|c|c|c|c|}
\hline \multirow[t]{2}{*}{$\begin{array}{l}\text { Rodzaj } \\
\text { czynnika }\end{array}$} & \multirow[t]{2}{*}{ Bariera } & \multicolumn{4}{|c|}{$\begin{array}{l}\text { Procentowy udział barier w zależności } \\
\text { od wielkości przedsiębiorstwa } \\
\text { (wg liczby zatrudnionych pracowników) }\end{array}$} \\
\hline & & $<49$ & $50-249$ & $250-499$ & $500>$ \\
\hline \multirow{3}{*}{$\begin{array}{l}\text { Czynniki } \\
\text { finansowe }\end{array}$} & $\begin{array}{l}\text { brak środków finansowych } \\
\text { w przedsiębiorstwie }\end{array}$ & 33,2 & 29,7 & 23,8 & 21,3 \\
\hline & $\begin{array}{l}\text { brak środków finansowych } \\
\text { ze źródeł zewnętrznych }\end{array}$ & 28,0 & 25,3 & 20,1 & 17,2 \\
\hline & zbyt wysokie koszty innowacji & 35,7 & 31,7 & 28,4 & 21,9 \\
\hline \multirow{4}{*}{$\begin{array}{l}\text { Czynniki } \\
\text { związane } \\
\text { z wiedzą }\end{array}$} & brak wykwalifikowanego personelu & 16,0 & 12,1 & 8,2 & 7,6 \\
\hline & brak informacji na temat technologii & 13,5 & 10,3 & 8,0 & 7,1 \\
\hline & brak informacji na temat rynków & 12,8 & 10,0 & 6,8 & 7,1 \\
\hline & $\begin{array}{l}\text { trudności w znalezieniu partnerów do } \\
\text { wspólpracy w zakresie działalności inno- } \\
\text { wacyjnej }\end{array}$ & 18,4 & 13,5 & 9,1 & 7,3 \\
\hline \multirow{2}{*}{$\begin{array}{l}\text { Czynniki } \\
\text { rynkowe }\end{array}$} & $\begin{array}{l}\text { rynek opanowany } \\
\text { przez dominujące przedsiębiorstwa }\end{array}$ & 22,9 & 17,5 & 13,0 & 15,3 \\
\hline & niepewny popyt na innowacyjne produkty & 23,1 & 18,8 & 15,4 & 15,3 \\
\hline \multirow[t]{2}{*}{$\begin{array}{l}\text { Pozostałe } \\
\text { czynniki }\end{array}$} & $\begin{array}{l}\text { brak potrzeby prowadzenia działalności } \\
\text { innowacyjnej ze względu na wprowadze- } \\
\text { nie innowacji w latach poprzednich }\end{array}$ & 15,8 & 11,6 & 7,0 & 7,3 \\
\hline & brak popytu na innowacje & 16,3 & 11,6 & 9,5 & 8,3 \\
\hline
\end{tabular}

Źródło: opracowanie własne na podstawie GUS, 2011. 
wynoszącą 35,7\% wskazań spośród ankietowanych podmiotów.

Mniej wskazań, aczkolwiek wciąż relatywnie dużo, zanotowały bariery o charakterze rynkowym, jak rynek opanowany przez przedsiębiorstwa dominujące oraz niepewny popyt na innowacyjne produkty, które wśród firm dużych zostały wskazane przez około $13-15 \%$, a w przypadku firm najmniejszych przez blisko $23 \%$ respondentów.

Relatywnie najmniej uciążliwe wydają się dla badanych firm bariery związane z dostępem do wiedzy, jak brak informacji na temat technologii i rynków. W przypadku bariery związanej z trudnościami w znalezieniu partnerów do współpracy w zakresie działalności innowacyjnej można natomiast zauważyć największą względną różnicę pomiędzy liczbą wskazań przez przedstawicieli firm o największej liczbie pracowników, wśród których tylko 7,3\% widzi taki problem, a liczbą wskazań przez przedstawicieli firm zatrudniających najmniej pracowników, wśród których aż 18,4\% twierdzi, że jest to istotna bariera.

Również pozostałe dwie bariery, czyli brak potrzeby prowadzenia działalności innowacyjnej ze względu na wprowadzenie innowacji w latach poprzednich oraz brak popytu na innowacje zostały wskazane przez mniejszą liczbę respondentów, niezależnie czy wśród firm większych, czy mniejszych.

Podsumowując badania przeprowadzone przez GUS, przedsiębiorcy najbardziej narzekają na bariery o charakterze finansowym, a w niewiele mniejszym stopniu na bariery wynikające z czynników rynkowych. Inne bariery, jak na przykład związane $\mathrm{z}$ dostępem do wiedzy, są zdaniem przedsiębiorców mniej dokuczliwe.

Ciekawych wniosków dostarczają również wyniki badań przeprowadzonych wśród polskich mikroprzedsiębiorstw przez Juchniewicz i Grzybowską, które dzielą bariery utrudniające wdrażanie innowacji na wewnętrzne i zewnętrzne (Juchniewicz i Grzybowska, 2010, s. 101-104). Do wewnętrznych zaliczają one: (1) niewystarczające środki finansowe; (2) niewystarczające zaplecze techniczne; (3) zbyt małe doświadczenie we wdrażaniu innowacji; (4) niewystarczającą informację na temat potrzeb rynkowych; (5) niewystarczająca informację na temat nowoczesnych technologii; (6) brak działu badawczo-rozwo- jowego; (7) niewłaściwy system nagród; (8) zbyt małe poparcie ze strony kierownictwa; (9) zbyt niski poziom kwalifikacji pracowników oraz (10) opór przed wdrażaniem nowości z ich strony.

Wśród barier o charakterze zewnętrznym wyróżniają one: (1) wysokie koszty innowacji; (2) utrudniony dostęp do zewnętrznych źródeł finansowania; (3) utrudniony dostęp do funduszy europejskich; (4) zbyt dużą biurokrację w urzędach administracji publicznej; (5) zbyt wysoki poziom ryzyka ekonomicznego działalności innowacyjnej; (6) mały popyt na innowacje; (7) niesprzyjająca innowacjom politykę państwa; (8) niesprzyjającą innowacjom politykę władz lokalnych; (9) brak instytucji wspierających transfer techniki oraz (10) brak jasnych koncepcji rozwoju regionalnego.

$\mathrm{Na}$ podstawie wyników badań przeprowadzonych przez Juchniewicz i Grzybowską można wyodrębnić dwie nowe grupy barier, które nie pojawily się we wcześniej prezentowanych zestawieniach. Sa to bariery o charakterze prawnym, jak niesprzyjająca polityka państwa i władz lokalnych czy nadmierna biurokracja urzędników oraz technologiczne, jak brak działu badawczo-rozwojowego czy niewystarczające zaplecze techniczne do wdrażania innowacji. Istnienie tych pierwszych ma niebagatelny wpływ na szybkość oraz skuteczność działalności innowatorów na rynku, a także na perspektywy rozwoju innowacyjności całej gospodarki. Te drugie są natomiast szczególnie widoczne w polskich przedsiębiorstwach, konkurujących z firmami zagranicznymi, dla których brak dostępu do nowoczesnych technologii oznacza zmniejszenie szans na wdrożenie innowacji, a w efekcie coraz częściej przymus opuszczenia rynku.

Występowanie większości powyżej wymienionych barier potwierdzają badania Pentora przeprowadzone wśród małych i średnich rodzinnych przedsiębiorstw innowacyjnych w Polsce. Ponadto, wśród wyników badań można znaleźć wiele informacji na temat barier charakterystycznych dla tych specyficznych podmiotów. $Z$ dziesięciu wyodrębnionych w wyniku badania przeszkód, pięć pierwszych jest charakterystycznych dla sektora małych i średnich firm, pozostałe zaś są popularne wśród przedsiębiorstw rodzinnych (Pentor, 2009, s. 49-52): 1) brak kapitału na cele inwestycyjne; 
2) bariery o charakterze podatkowym oraz fiskalnym, związane z prowadzeniem działalności innowacyjnej;

3) ograniczenie zakresu inwestycji i działania przez bariery prawne i administracyjne;

4) trudności ze znalezieniem odpowiednio wykwalifikowanych kadr pracowniczych;

5) bariery technologiczne, wynikające $\mathrm{z}$ braku dostępu do nowoczesnej aparatury oraz pojawiających się na rynku innowacji technicznych;

6) brak odpowiednio wykwalifikowanych kadr menedżerskich lub silne ograniczenie ich działania przez członków rodziny właścicielskiej;

7) bariery w kulturze organizacyjnej, które są wynikiem nepotyzmu właścicieli oraz rodzinnej atmosfery w firmie;

8) problemy z sukcesją, ze zmianą pokolenia zarządzającego firmą, które mogą powodować kryzysy w firmie;

9) charakter założyciela firmy, który często dąży do autokratyzmu w sterowaniu przedsiębiorstwem;

10) bariery będące efektem rozbieżności pomiędzy celami przedsiębiorstwa a celami rodziny właścicielskiej.

Wyniki badań Pentora wskazują, że mali i średni przedsiębiorcy z sektora firm rodzinnych, obok problemów charakterystycznych dla przedsiębiorczości rodzinnej, zauważają te same rodzaje barier w działalności innowacyjnej, co ankietowani w wymienionych wcześniej badaniach. Do największych $z$ nich zaliczają oni te o charakterze finansowym, prawnym, organizacyjnym oraz technologicznym.

Matusiak z Gulińskim i zespołem zwracają natomiast uwagę na problem, który stanowią preferencje instytucji inwestycyjnych (Matusiak i Guliński, 2010, s. 47). Wolą one bowiem wspierać projekty o charakterze nietechnicznym, charakteryzujace się mniejszym stopniem ryzyka niż innowacje technologiczne, które wymagają najczęściej większych nakładów oraz dłuższego okresu potrzebnego do ich realizacji.

Co więcej autorzy ci zauważają, że finansowe mechanizmy wsparcia innowacji są mało efektywne, co wynika ze źle określonego celu ich przeznaczenia, uzależnionego od procedur, a nie od chęci zrealizowania merytorycznie uzasadnionych przedsięwzięć. Do czterech podstawowych barier, które pojawiają się podczas wykorzysty- wania środków pomocowych przez polskie przedsiębiorstwa, autorzy zaliczają (Matusiak i Guliński, 2010, s. 30):

1) zbyt dużą formalizację i ,proceduralizacje” mechanizmów wsparcia, prowadzącą do nieefektywnego wydatkowania środków;

2) nieokreśloną kwestię kontynuacji programów pomocowych po zakończeniu finansowania i niedokładne ich dostosowanie do specyfiki regionu;

3) niedojrzałą i nieprzejrzystą politykę innowacyjną w regionach, charakteryzującą się niehierarchicznym postępowaniem i dużym rozwodnieniem przedsięwzięć promujących innowacyjność;

4) brak jednoznacznej, odgórnej polityki innowacyjnej powodującej brak koordynacji postępowania i deficyt planów rozwoju innowacyjności.

Piszą też, że za słaby stan polskiej innowacyjności są również odpowiedzialni polscy konsumenci, nieufni wobec rodzimych jednostek badawczo-rozwojowych i niechętnie wybierający polskie nowinki technologiczne.

Wspomniani powyżej badacze przeprowadzili także analizę barier pojawiających się $w$ procesie transferu technologii, od którego skuteczności ściśle zależy prawidłowy rozwój innowacyjności w całej gospodarce. Okazuje się, że w kontaktach pomiędzy sektorami nauki i biznesu istnieje duża ilość odmiennych wizji działania, prowadzących do nieporozumień, a nawet jawnej wrogości. Efektem takiego stanu jest brak skutecznej współpracy pomiędzy tymi dwoma sektorami oraz upośledzony proces rozwijania innowacji i przenikania ich $\mathrm{z}$ nauki do biznesu.

Wśród barier generowanych przez polskich przedsiębiorców autorzy wymieniają: (1) imitacyjny styl przedsiębiorczości, opierający się na adoptowaniu rozwiązań sprawdzonych za granica; (2) brak zaufania przedsiębiorców do jakości wiedzy powstającej w rodzimych jednostkach naukowobadawczych i (3) obawę przed niewystarczającym przygotowaniem tych jednostek do efektywnej współpracy z przedsiębiorcami.

Barierami powstającymi po stronie jednostek naukowo-badawczych są natomiast według autorów: (1) brak efektów zmian transformacyjnych, które zaszły na rodzimych uczelniach i w jednostkach naukowobadawczych po 1989 roku; (2) wysoki fiskalizm tych jednostek, który wpływa na ich 
niską adaptację do warunków rynkowych; (3) brak określonych reguł zarządzania wiedzą i łączenia działalności naukowej z biznesową; (4) brak określonych regulaminów, wzorów umów kontraktów badawczych czy też dokumentów dotyczących ochrony praw własności intelektualnej; (5) brak odczuwalnych korzyści finansowych przez pracowników naukowych podejmujących prace badawcze; (6) przeświadczenie świata nauki o większym znaczeniu badań podstawowych od prac rozwojowych oraz o sprzeczności działalności gospodarczej z etosem pracy naukowej (Matusiak i Guliński, 2010, s. 30).

Powyższe bariery wskazują na istnienie bardzo poważnych tarć pomiędzy przedstawicielami środowiska naukowego i świata biznesu. Efektem tego jest wzajemna niechęć, brak zaufania oraz duża niepewność dotycząca ewentualnych wspólnych przedsięwzięć. Niestety, taki stan jest podtrzymywany przez hermetyczność struktur w jednostkach naukowo-badawczych oraz szereg stereotypów, które pozostały jeszcze z lat 80., a które wpływają na ocenę w oczach przedsiębiorców.

Cztery główne rodzaje barier, które wymieniają autorzy to bariery (Matusiak i Guliński, 2010, s. 30):

1) o charakterze strukturalnym, które pojawiają się zarówno w sektorze nauki, jak i biznesu, a które wynikają z braku określonej strategii i polityki działania;

2) systemowe, związane $z$ przesytem regulacji prawnych, uniemożliwiających rozwój innowacji oraz zmniejszających skuteczność działania sektora badawczego;

3) natury świadomościowo-kulturowej, wynikające $\mathrm{z}$ utrwalonych stereotypów oraz postaw naukowców i przedsiębiorców, wpływających na brak wzajemnego zaufania obydwu stron oraz niski poziom akceptacji polskich innowacji przez polski sektor biznesu;

4) kompetencyjne występujące w jednostkach naukowo-badawczych i wśród przedsiębiorców, które prowadzą do niedostatecznej współpracy $\mathrm{w}$ ramach technologii innowacyjnych.

$\mathrm{O}$ barierach dla transferu techniki pisze także Jasiński, który przeprowadził badanie m.in. wśród polskich ekspertów zajmujących się tematyką innowacyjności i transferu technologii. Autor dzieli wskazane przez ankietowanych bariery na trzy pod- stawowe grupy (Jasiński, 2006, s. 150-151): kluczowe, szczególnie ważne oraz pozostałe, o mniejszej istotności. I tak, wśród barier kluczowych znajdują się: (1) niska otwartość i brak odpowiedniej gotowości jednostek naukowo-badawczych do współpracy z przedsiębiorstwami; (2) mało sprawne systemy wspierania innowacyjności przedsiębiorstw i ich współpracy ze sferą nauki; (3) problemy przedsiębiorstw związane z małą ilością własnych środków finansowych i (4) z ich pozyskiwaniem ze źródeł zewnętrznych, a także (5) zdecydowanie za mała kultura innowacyjna widoczna w działalności polskich firm.

Wśród barier transferu techniki określonych przez Jasińskiego, jako szczególnie ważne, znajdują się (1) mała chłonność innowacji w gospodarce; (2) mała sprawność działania jednostek infrastruktury transferu techniki, takich jak parki naukowo-techniczne, instytucje pomostowe czy firmy odpryskowe; (3) nikłe finansowanie $\mathrm{z}$ narodowego systemu innowacji oraz (4) omijanie sektora badań i rozwoju na rzecz bezpośrednich inwestycji zagranicznych.

Do pozostałych barier, o mniejszym znaczeniu, zalicza on natomiast (1) wąską ofertę jednostek naukowo-badawczych; (2) małą ilość informacji o innowacjach docierająca do świata biznesu; (3) brak doświadczenia, odpowiednich kwalifikacji oraz wystarczającej motywacji menedżerów zajmujących się tematyką innowacji; (4) brak regulacji prawnych i finansowych wspierających transfer techniki; (5) działalność badawczo-rozwojową wewnątrz firm; (6) brak jednoznacznej zorientowanej na innowacje strategii oraz (7) oderwanie nauki akademickiej od świata techniki i laboratoriów.

Przytoczone powyżej wyniki badań wskazują na różnoraki charakter barier występujących w działalności innowacyjnej oraz w procesie transferu techniki. Ponadto, każda $\mathrm{z}$ nich jest odczuwana w różnym stopniu przez poszczególne firmy i z odmiennym natężeniem wpływa na ich innowacyjność. Często istotność danej bariery dla przedsiębiorstwa zależy od jego formy organizacyjno-prawnej, od działu gospodarki, w której ono funkcjonuje, czy też, jak potwierdziły badania przeprowadzone przez GUS, od wielkości firmy.

Autorzy wymienionych powyżej badań podjęli próbę zaszeregowania opisywanych 
barier, tworząc $\mathrm{z}$ nich grupy o podobnej genezie. Odpowiednia selekcja barier ułatwia również całościowe spojrzenie na ich istotę, a co za tym idzie na możliwości ich przezwyciężenia. Trzy podstawowe grupy barier w działalności innowacyjnej, wyodrębnione do dalszej analizy, to: (1) bariery o charakterze finansowym; (2) bariery występujące podczas współpracy pomiędzy sektorami nauki i biznesu oraz (3) bariery o podłożu prawnym. W ramach każdej z grup znajdują się przeszkody posiadające wspólne cechy, decydujące o ich uciązliwości dla polskich innowatorów. Takie ich zestawienie umożliwia również wytypowanie szeregu czynników, które mogą pomóc w ich zwalczeniu. W dalszej części artykułu została przeprowadzona analiza poszczególnych grup barier oraz przedstawiono propozycje dotyczące sposobów ich przezwyciężania.

\section{Sposoby przełamywania barier o charakterze finansowym}

Najczęściej pojawiającym się problemem w działalności innowacyjnej jest niedostateczna ilość środków finansowych. Brakuje ich zarówno w trakcie rozwoju innowacji od pierwszego pomysłu do pierwszego wdrożenia, jak i podczas prac nad jego dyfuzja na rynku. Pojawiają się trudności z realizacją celów rozwojowych przedsiębiorstw, takich jak pozyskiwanie nowych rozwiązań technicznych oraz udoskonalanie posiadanego wyposażenia i urządzeń. Problem ten wynika przede wszystkim $\mathrm{z}$ wysokich kosztów transferu techniki oraz zbyt małej pomocy administracji publicznej w dofinansowaniu działań innowacyjnych przedsiębiorców.

Na brak wystarczających środków finansowych wśród polskich firm innowacyjnych zwraca uwagę chociażby Jasiński (2006, s. 133), który stwierdza, że ich niedobór „ma bezpośredni związek z wysokimi kosztami działalności”. Autor ten porusza też temat niedostatecznej współpracy przedsiębiorstw innowacyjnych $\mathrm{z}$ jednostkami sektora finansowego, które proponują niedogodne warunki kredytowania przedsięwzięć oraz gwarantowania badań z funduszy poręczeniowych i pożyczkowych.

Jasiński widzi jednak szanse na przezwyciężenie barier innowacji o charakterze finansowym. Na podstawie wyników ankiety przeprowadzonej wśród przedsię- biorców, proponuje pięć sposobów naprawy sytuacji ekonomicznej firm innowacyjnych (Jasiński, 2006, s. 134-135):

1) powiększenie puli dotacji na cele badawczo-rozwojowe oraz ułatwienie dostępu do nich firmom innowacyjnym;

2) zwiększenie ilości środków pomocowych oraz ułatwienie dostępu do nich;

3) powiększenie udziału państwowych nakładów na cele badawczo-rozwojowe;

4) ułatwienie dostępu do informacji o programach pomocowych i dotacjach na innowacje;

5) zmniejszenie podatków związanych $\mathrm{z}$ działalnością innowacyjną.

$\mathrm{Z}$ kolei w badaniach przeprowadzonych przez Ceterę wśród małych i średnich firm branży poligraficznej pojawiają się takie argumenty, jak obawa przed uzależnieniem się od instytucji finansowych czy występowanie niespójności procedur pozyskiwania środków. Odzwierciedlają one pozycję polskich firm, zwłaszcza tych biedniejszych, które w sytuacji braku środków na działalność oraz istotnych problemów $\mathrm{z}$ ich pozyskaniem, są zmuszane do zaniechania planów wdrożeniowych. Autor wskazuje również na szereg propozycji respondentów, dotyczących przełamywania barier finansowych w innowacjach (Cetera, 2010, s. 170-171):

1) zmniejszenie kosztów kredytów na innowacje;

2) wprowadzenie tańszych kredytów na zakup środków produkcji;

3) wprowadzenie subsydiów na innowacje oraz ulg podatkowych;

4) uproszczenie procedur, których celem jest pozyskanie poręczeń kredytowych na zakup nowych technologii;

5) uproszczenie procedur finansowania rozwoju innowacyjnych przedsięwzięć;

6) skrócenie okresu amortyzacji środków trwałych;

7) dopłaty do działalności badawczorozwojowej oraz na cele innowacyjne;

8) dopłaty na cele związane $z$ promocją innowacji.

Można polemizować czy polscy innowatorzy nie powinni w pierwszej kolejności poszukać drogi do efektywniejszego zarządzania własnym przedsiębiorstwem. $\mathrm{Na}$ pewno warto zacząć od wprowadzenia praktyk, które uskuteczniłyby proces gospodarowania finansami wewnątrz tych podmiotów. Takie działania wymagają jednak na dłuższą metę wsparcia od 
instytucji administracji publicznej, a jak potwierdzają wyniki badań, postulaty innowacyjnych polskich przedsiębiorców, dotyczące zwalczania barier o charakterze finansowym, są skierowane głównie poza firme.

Nie ulega wątpliwości, że innowatorzy mają problemy z finansowaniem działalności ze środków własnych. Nie jest też rzeczą dziwną, że w takiej sytuacji poszukuja wsparcia dla swoich inwestycji ze źródeł zewnętrznych. Wydaje się, że szans na przełamanie barier o charakterze finansowym należy upatrywać przede wszystkim w działaniach administracji rządowej, która powinna wziąć większą odpowiedzialność za rozwój polskich innowacji. Można wyróżnić trzy sposoby rozwiązania tego problemu: (1) ciągłe rozszerzanie możliwości finansowania przedsięwzięć innowacyjnych poprzez zwiększanie poziomu dotacji na innowacje i na prace badawczo-rozwojowe; (2) ułatwianie dostępu do środków większej liczbie innowatorów oraz (3) stworzenie bardziej dogodnych warunków kredytowania działalności innowacyjnej.

\section{Pokonywanie barier we współpracy pomiędzy sektorami nauki i biznesu}

Jasiński twierdzi, że podstawową przeszkodą w kontaktach pomiędzy światem nauki i biznesu w Polsce jest „słabość samej nauki i jej oferty". Wskazuje on jednocześnie na istotny problem w działalności innowacyjnej, jakim jest pasywna postawa polskich jednostek naukowo-badawczych w stosunku do współpracy z przedsiębiorcami (Jasiński, 2006, s. 133).

Przezwyciężenie barier pomiędzy sektorami nauki i biznesu wymaga podjęcia działań przez każdą ze stron, jednak można odnieść wrażenie, że najwięcej pracy jest do wykonania w jednostkach naukowo-badawczych. Jasiński wskazuje na trzy najważniejsze postulaty skierowane w ich stronę przez przedsiębiorców (2006, s. 135):

1) usprawnienie procesów związanych $\mathrm{z}$ zarządzaniem jednostkami naukowobadawczymi i ich finansowaniem, co skutkowałoby lepszym ich funkcjonowaniem i szerszą, tańszą oraz bardziej innowacyjną ofertą naukową;

2) odnalezienie nowych sposobów wykorzystania wyników prac badawczo-rozwojowych w praktyce;
3) zintensyfikowanie kontaktów pomiędzy przedstawicielami świata nauki i biznesu. Autor ten zamieszcza też swoje propozycje działań dla jednostek naukowo-badawczych, które mogłyby zniwelować problem słabej współpracy pomiędzy naukowcami i przedsiębiorcami w Polsce. Sa to (Jasiński, 2006, s. 157): (1) lepsze przygotowanie i gotowość do współpracy z firmami; (2) szersza oferta innowacyjnych rozwiązań naukowo-technicznych oraz (3) ułatwienie dla nich dostępu do rynku; (4) usprawnienie ich zarzadzania i funkcjonowania; (5) utworzenie silniejszych powiązań z przedsiębiorcami, zwłaszcza z sektora MŚP; (6) ułatwienie młodzieży akademickiej większego dostępu do praktyk w laboratoriach badawczych, a także (7) przeprowadzenie działań o charakterze marketingowym, mających na celu łatwiejsze przedostawanie się opracowanych technologii do sektora biznesu.

W podobnym tonie wypowiada się Mackiewicz, która wskazuje na następujące sposoby przeciwdziałania tym barierom (2007, s. 54):

1) zwiększenie mobilności naukowców oraz przepływu kadr naukowych;

2) doprowadzenie do bardziej dogłębnej wymiany wiedzy technicznej oraz doświadczeń między przedstawicielami obydwu środowisk;

3) tworzenie wspólnych projektów badawczych;

4) tworzenie konsorcjów badawczych;

5) intensywniejsze tworzenie firm odpryskowych, typu spin-off;

6) chętniejsze licencjonowanie innowacyjnych rozwiązań przedsiębiorcom;

7) otwieranie wspólnych inwestycji infrastrukturalnych oraz wspólnych laboratoriów badawczych;

8) nawiazywanie nieformalnych powiązań pomiędzy przedstawicielami obu środowisk;

9) ułatwienie przepływu absolwentów uczelni do przedsiębiorstw.

Spełnienie wszystkich powyższych oczekiwań jest trudne. Należy bowiem przeprowadzić wiele zmian w strukturach uczelni oraz instytutów badawczych i zmienić sposób myślenia niektórych pracowników naukowych. Aby przełamać marazm w kontaktach pomiędzy polskimi naukowcami a przedsiębiorcami, potrzebna jest jednak przede wszystkim zmiana podejścia świata nauki do sposobu prowadzenia prac 
badawczych oraz wzmocnienie wzajemnego zaufania każdej ze stron.

Dodatkowo, należy szukać pomocy oraz oczekiwać konkretnych działań ze strony jednostek infrastruktury transferu techniki, takich jak inkubatory innowacji, parki naukowo-technologiczne, centra technologiczne, instytucje pomostowe czy też firmy odpryskowe, które ułatwiają praktyczne wykorzystanie rozwiązań naukowo-technicznych powstajacych w ramach badań. Jasiński wskazuje cztery rodzaje działań, dzięki którym instytucje te moga przyczynić się do poprawy sytuacji na linii nauka-biznes (2006, s. 179):

1) wsparcie pracowników naukowych, doktorantów oraz studentów podczas rozpoczynania przez nich działalności gospodarczej;

2) pomoc w kwestiach ochrony praw własności intelektualnej;

3) pomoc w patentowaniu osiągnięć naukowców;

4) przeciwdziałanie negatywnym emocjom pomiędzy jednostkami naukowo-badawczymi a przedsiębiorstwami.

Rola jednostek infrastruktury transferu techniki w procesie przełamywania barier pomiędzy światem naukowym a biznesowym jest istotna. To od nich w dużej mierze zależy powodzenie misji, jaką jest przełamanie obustronnej niechęci oraz ukierunkowanie działań tych środowisk na osiąganie wspólnych sukcesów, naukowych i ekonomicznych.

Przede wszystkim jednak potrzebne są zmiany wewnątrz jednostek naukowobadawczych, które powinny opierać swoją działalność na wiedzy praktycznej, dostarczanej im przez przedsiębiorców oraz ukierunkować ją na tworzenie konkretnych rozwiązań dla świata biznesu. Najważniejszą rzeczą jest natomiast potrzeba pozytywnego spojrzenia tych placówek oraz firm na kwestię wzajemnej współpracy. Tylko wtedy można myśleć o realnym wzmocnieniu innowacyjności polskiej gospodarki.

\section{Przezwyciężanie przeszkód natury prawnej}

Do trzeciej grupy barier w działalności innowacyjnej należą te o charakterze prawnym. Wielu przedsiębiorców zwraca bowiem uwage na brak przyjaznych uregulowań prawnych, nadmierną biurokrację i długotrwałe procedury administracyjne, na niedostateczną uwagę władz państwowych skierowaną w stronę innowacyjnych firm, a także na powierzchowność w działaniach organów odpowiedzialnych za wykorzystanie środków pomocowych na innowacje.

Haffer i Haffer przeanalizowali potencjalne efekty zmian legislacyjnych, które mogłyby poprawić sytuację prawną polskich innowatorów (2008, s. 82). Oto najciekawsze wnioski z ich pracy:

1) należy wprowadzić ułatwienia prawne dla przedsiębiorstw aktywnie współpracujących z jednostkami naukowo-badawczymi, dzięki czemu będą one w stanie łatwiej wprowadzać innowacje na rynek;

2) istnieje potrzeba uproszczenia procedur starania się przedsiębiorców o środki pieniężne na innowacje;

3) niezbędne jest wprowadzenie zmian prawnych na poziomie centralnym, które doprowadziłyby do wypracowania jednoznacznych strategii działania w kwestii ochrony praw własności intelektualnej oraz usprawnienia systemu fiskalnego państwa.

Również Puchała-Krzywina przytacza postulaty przedsiębiorców dotyczące usprawnienia prawnych aspektów prowadzenia działalności innowacyjnej, wśród których znalazły się: (1) potrzeba uproszczenia przepisów dotyczących działalności gospodarczej; (2) wymóg przyspieszenia i ułatwienia procedur związanych z poszukiwaniem zewnętrznych źródeł finansowania oraz (3) potrzeba usprawnienia drogi do powołania centrum badawczo-rozwojowego (Puchała-Krzywina, 2011, s. 168).

O możliwości pokonywania barier natury prawnej piszą też Matusiak z Gulińskim i zespołem. Wskazują na siłę działań oddolnych, inspirowanych przez administrację lokalną. Mimo że ta forma gospodarowania środkami publicznymi przyczyniła się do aktywizacji firm innowacyjnych w wielu miejscach w kraju, jej potencjał w skali ogólnopolskiej jest wciąż niewykorzystany.

Autorzy ci zwracają też uwagę na obecność w Polsce wielu pozytywnych działań w dziedzinie rozwoju innowacyjności, jak ciągła restrukturyzacja czy zwiększenie efektywności gospodarowania zasobami i wiedzą. Istotny wpływ na rozwój innowacyjności polskiej gospodarki może 
mieć rozpoczęty już proces przenoszenia pomocy publicznej z dojrzałych rynkowo firm i branż w miejsca rozwoju innowacji i instrumentów komercjalizacji wiedzy (Matusiak i Guliński, 2010, s. 20-23).

Niebagatelny wpływ na rozwój innowacyjności miały też Fundusze Europejskie, które poluzowały wiele barier. Przykładowo Program Operacyjny Innowacyjna Gospodarka $z$ lat programowania 2007-2014 składał się z 9 osi priorytetowych: (1) badania i rozwój nowoczesnych technologii; (2) infrastruktura sfery B+R; (3) kapital dla innowacji; (4) inwestycje w innowacyjne przedsięwzięcia; (5) dyfuzja innowacji; (6) polska gospodarka na rynku międzynarodowym; (7) społeczeństwo informacyjne - budowa elektronicznej administracji; (8) społeczeństwo informacyjne - zwiększenie innowacyjności gospodarki oraz (9) pomoc techniczna. W ramach Programu udało się wesprzeć działania polskich przedsiębiorstw, wśród których do połowy 2013 roku w skali całego kraju umowę o dofinansowanie podpisało przeszło 6 podmiotów na 1000 (Ministerstwo Rozwoju Regionalnego, 2013, s. 19-20).

Pomimo tego sukcesu, można odnieść wrażenie, że ciągle istnieje konieczność zweryfikowania zapisów prawnych, dotyczących działalności innowacyjnej. Przedsiębiorcy domagają się bowiem większej pomocy ze strony państwa, zdecydowanego uproszczenia przepisów oraz długotrwałej, spójnej polityki, dotyczącej innowacji.

Pokonanie barier prawnych wymaga bowiem zmiany sposobu myślenia ustawodawców, którego efektem byłby projekt długotrwałego systemu wsparcia innowatorów oraz kompleksowego zarządzania całym sektorem innowacji. Pozytywne i wsparte jednoznacznym prawem spojrzenie władz w stronę rozwoju rodzimej innowacyjności pozwoliłoby na podniesienie konkurencyjności całej polskiej gospodarki.

\section{Konkluzje}

Można odnieść wrażenie, że problemy przedstawione $\mathrm{w}$ ramach każdej $\mathrm{z}$ grup barier innowacyjności w Polsce przenikaja się wzajemnie. Należy również szukać rozwiązań, które umożliwiłyby kompleksowe podejście do tematyki barier i zmniejszenie ich odczuwalności. Istnieją takie przeszkody, które mają różnoraką genezę, a ich przezwyciężenie zależy od skutecznego zrealizowania zadań w kilku obszarach jednocześnie. Przykładowo, opisywane w pierwszej części artykułu bariery o charakterze technologicznym oraz zwiazane z niewystarczajacca wiedza innowatorów niejednokrotnie mają wspólne podłoże finansowe.

W jeszcze innych przypadkach przezwyciężenie jednej bariery prowadzi do rozwiązania szeregu pozostałych problemów. Przykładem może być tutaj kwestia uproszczenia zapisów prawnych, związanych z procesem starania się o środki finansowe na innowacje. Wprowadzenie takiego rozwiązania miałoby pozytywny wpływ na sytuację finansową innowacyjnych przedsiębiorców, jak również mogłoby uaktywnić bardziej przedsiębiorczych naukowców do działalności rynkowej.

Pomimo wykorzystania środków unijnych, głównie w ramach Programu Operacyjnego Innowacyjna Gospodarka, wciąż odczuwalna jest mało przyjazna polityka państwa wobec innowatorów, która przekłada się nie tylko na wzrost poziomu barier o charakterze prawnym, lecz także na współpracę pomiędzy sektorem nauki i biznesu oraz na poziom finansów w przedsiębiorstwach innowacyjnych. Analogicznie, większa ilość środków budżetowych na innowacje mogłaby spowodować, że pracownicy naukowi byliby bardziej otwarci w kontaktach ze sferą biznesu, gdyż wspólne z przedsiębiorstwami projekty mogłyby stanowić dla nich dodatkową szansę rozwoju, osiągnięcia profitów finansowych oraz pewniejszej pozycji wśród naukowców.

Propozycje działań przedstawione w tabeli 3 stanowią główne postulaty wobec przedsiębiorców, jednostek naukowobadawczych oraz administracji państwowej, których zrealizowanie może się przyczynić do przezwyciężenia barier $\mathrm{w}$ działalności innowacyjnej.

Aby umożliwić stworzenie odpowiednich warunków pracy dla innowatorów, należy dokonać zmian na najwyższych szczeblach władzy. To decyzje władz państwowych mają największy wpływ na stan innowacyjności polskiej gospodarki. Nowe spojrzenie na ten problem jest niezbędne, by realnie usprawnić rodzimą działalność innowacyjną oraz proces transferu techniki pomiędzy polskimi jednostkami naukowobadawczymi a firmami. 
Tabela 3. Lista propozycji działań mających na celu przełamanie każdej z grup barier skierowana do poszczególnych podmiotów zaangażowanych w rozwój działalności innowacyjnej w Polsce

\begin{tabular}{|c|c|c|c|}
\hline \multirow{2}{*}{$\begin{array}{l}\text { Grupy } \\
\text { barier }\end{array}$} & \multicolumn{3}{|c|}{ Propozycje działań dla poszczególnych podmiotów } \\
\hline & przedsiębiorstwa & $\begin{array}{c}\text { jednostki } \\
\text { naukowo-badawcze }\end{array}$ & administracja państwowa \\
\hline 疍 & $\begin{array}{l}\text { zwiększenie } \\
\text { efektywności } \\
\text { zarządzania } \\
\text { finansami przez } \\
\text { przedsiębiorstwa }\end{array}$ & $\begin{array}{l}\text { zwiększenie efektywności } \\
\text { zarządzania finansami } \\
\text { przez jednostki naukowo- } \\
\text { badawcze }\end{array}$ & $\begin{array}{l}\text { 1) zwiększanie poziomu } \\
\text { dotacji na innowacje } \\
\text { 2) ułatwienie dostępu do } \\
\text { środków pomocowych } \\
\text { większej liczbie } \\
\text { przedsiębiorstw } \\
\text { 3) oddziaływanie na banki, by } \\
\text { stworzyły lepsze warunki } \\
\text { kredytowania działalności } \\
\text { innowacyjnej }\end{array}$ \\
\hline 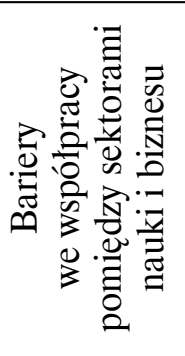 & $\begin{array}{l}\text { zacieśnienie powiązań } \\
\text { z przedstawicielami } \\
\text { jednostek naukowo- } \\
\text { badawczych }\end{array}$ & $\begin{array}{l}\text { 1) oparcie działalności } \\
\text { na wiedzy praktycznej, } \\
\text { dostarczanej przez } \\
\text { przedsiębiorców } \\
\text { 2) ukierunkowanie } \\
\text { działań na tworzenie } \\
\text { rozwiązań dla świata } \\
\text { biznesu }\end{array}$ & $\begin{array}{l}\text { wsparcie działalności } \\
\text { jednostek infrastruktury } \\
\text { transferu techniki }\end{array}$ \\
\hline 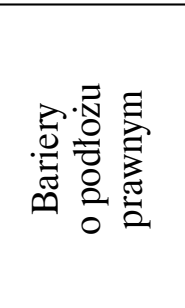 & - & - & $\begin{array}{l}\text { 1) uproszczenie przepisów } \\
\text { dotyczących działalności } \\
\text { gospodarczej } \\
\text { 2) ułatwienia prawne dla } \\
\text { przedsiębiorców aktywnie } \\
\text { współpracujących z jednost- } \\
\text { kami naukowo-badawczymi }\end{array}$ \\
\hline
\end{tabular}

Źródło: opracowanie własne.

\section{Bibliografia}

Cetera, W. (2010). Skazani na wyobraźnię. Zachowania innowacyjne matych i średnich przedsiębiorstw poligraficznych $w$ świetle badań empirycznych. Warszawa: Promocja XXI.

GUS. Informacja sygnalna. (2013). Dziatalność innowacyjna przedsiębiorstw w latach 2010-2012. Warszawa: Informacje i opracowania statystyczne. Pozyskano z: http:/www.stat.gov.pl/cps/rde/xbcr/ szczec/ASSETS_sygnalna_DI.pdf (21.12. 2013).

GUS. Urząd Statystyczny w Szczecinie. (2011). Dziatalność innowacyjna przedsiębiorstw $w$ latach 2008-2010. Warszawa: Informacje i opracowania statystyczne.

Haffer, M. i Haffer, R. (red.) (2008). Aktywność innowacyjna matych $i$ średnich przedsiębiorstw Pomorza i Kujaw. Toruń: Wydawnictwo Naukowe UMK.

Janasz, W. (1999). Innowacyjne strategie rozwoju przemystu. Szczecin: Fundacja Uniwersytetu Szczecińskiego
Janasz, W. (red.) (2003). Innowacje w modelach działalności przedsiębiorstw. Szczecin: Wydawnictwo Naukowe Uniwersytetu Szczecińskiego.

Jasiński, A. (2006). Innowacje i transfer techniki $w$ procesie transformacji. Warszawa: Difin.

Juchniewicz, M. i Grzybowska, B. (2010). Innowacyjność mikroprzedsiębiorstw $w$ Polsce. Warszawa: PARP.

Komisja Europejska. (2013). Innovation Union Scoreboard. Bruksela: Komisja Europejska. Pozyskano z: http://ec.europa.eu/enterprise/policies/ innovation/files/ius-2013_en.pdf (30.01.2014).

Mackiewicz, M. (2007). W: M.A. Weresa (red.), Transfer wiedzy z nauki do biznesu. Doświadczenia regionu Mazowsze. Warszawa: OW SGH.

Matusiak, K. i Guliński, J. (red.) (2010). System transferu technologii i komercjalizacji wiedzy w Polsce - Sity motoryczne i bariery. Warszawa: PARP.

Ministerstwo Rozwoju Regionalnego. (2013). Sprawozdanie okresowe z realizacji Programu Ope- 
racyjnego Innowacyjna Gospodarka, 2007-2013 za I pótrocze 2013 r. Pozyskano z: https:/www.poig.gov. pl/AnalizyRaportyPodsumowania/poziom/Documents/Sprawozdanie_POIG_I_POLROCZE_2013. pdf (5.05.2014).

Pentor, (2009). Badanie firm rodzinnych - raport końcowy. Warszawa: PARP.

Pomykalski, A. (2001). Innowacje. Łódź: Politechnika Łódzka.
Puchała-Krzywina, E. (2011). Czynniki ograniczające aktywność innowacyjną przedsiębiorstw w latach 2007-2009. W: T. Baczko (red.). Raport o innowacyjności gospodarki Polski w 2010 roku. Warszawa: INE PAN.

Rogers, E. (2003). Diffusion of innovations. New York: Free Press. 